Check for updates

1 The UK Health Alliance on Climate Change

Cite this as: $B M J 2021 ; 375: n 2788$ http://dx.doi.org/10.1136/bmj.n2788 Published: 14 November 2021

\title{
COP26 diary: Health at last get its big day (well, hour)
}

\section{Richard Smith chair}

\section{Tuesday 9 November}

Today is my last day at COP26, and I'm full of admiration for those people who stick out the whole two weeks. I'd go crazy. But today is a special day, it's science day-and health has been squeezed into the programme. Patricia Espinosa, the executive secretary of the United Nations Framework Convention on Climate Change, and Sajid Javid, the UK's Secretary of State for Health and Social Care, are expected to attend a one-hour session on health.

We, the health people, are excited that our day has come, and we start queuing for seats some 40 minutes before the session is to begin. We have the satchel brought by cycling health professionals from Geneva to Glasgow and a cardboard poster summarising the healthy prescription letter. The hope of being able to present both to Alok Sharma, the COP26 president, is fading, but Espinosa is second choice. We are to be granted two minutes at the beginning to be photographed with Espinosa. As I'm the only person available who did any of the cycling (and I did only one day) it's my job to grab Espinosa and be photographed with her. (It proved impossible to get any of the people who cycled all the way from London to Glasgow into the Blue Zone, and I'm only here because the Royal College of Psychiatrists had a spare space and kindly gave it to me.)

While in the queue we discuss breastfeeding, a discussion sparked by the observation that there are no babies-and almost no children-at COP26. Both the women I'm talking with have experience of breastfeeding, but we agree that it is becoming more difficult to breastfeed in public, perhaps explaining the lack of babies at COP26.

At last, the doors open, and we look for somebody to be photographed with. Unfortunately-but not surprisingly-neither Espinosa nor Javid are going to make the meeting, but we spot Gordon Brown, former prime minister and "the man who saved the world after the 2008 financial crash." I was at Edinburgh University with Brown and knew him because he edited the student newspaper when I edited the medical school magazine-and both were published from the same office. I saunter up to him and say "You probably don't remember me, but..." (My wife tells me later this was bad manners as such an introduction makes it impossible for the victims to do anything but pretend they remember you.) Brown, who must have the phrase said to him all the time, rises to the occasion and says with a big smile and says "Of course, and you've gone onto greater things..." This is, I suspect, a standard response.

As we are photographed, I explain to Brown about the cycle, the satchel, and the healthy prescription, and I read out to him some of the words written on the satchel by patients of Great Ormond Street Hospital: "Humans are the only creatures on the Earth that will cut down a tree, turn it into paper, then write "save the trees" on it"; and "Climate change affects everyone and with such great authority and status under your belt I'm sure you could do something about it.” Brown suggests that I read out some of these messages during the meeting. (It was a strictly choreographed meeting, and I had no chance, although I kept hoping that Brown might suggest to the chair that I read the messages. He didn't.)

We also manage a photo with Humza Yousaf, Scottish Cabinet Secretary for Health and Social Care. A Glasgow member of the Scottish parliament, he has to sit in the audience while two UK ministers feature on stage. I can imagine that he wasn't entirely content.

The show gets underway, facilitated by Maria Neira, the WHO director of environment, climate change, and health, whom I think of as the leader of us "health people who care about climate change." She's a marvellous facilitator who makes people laugh and feel good and destroys the pomposity that can suck the life out of meetings. The meeting started with a video made by the Global Climate and Health Alliance that features health workers describing the problems they were seeing from climate change and making a prescription: "I prescribe healthy air as a right for all children," says Mark Hayden, one of the main organisers of the Ride for Their Lives and an intensive care physician at Great Ormond Street Hospital. He also says: "I have seen children die because of the air quality of our streets."

Neira introduces Satyendra Prasad, Fiji's ambassador and permanent representative to the United Nations, and Rachel Levine, a four-star admiral and United States assistant secretary for health. They, one from a country that is a leading emitter of greenhouse gases and one from a country gravely threatened by climate change, stand side by side and read out that "a group of 50 countries have committed to develop climate-resilient and low-carbon health systems." I'm not sure exactly what that commits countries to, but the full list is online. ${ }^{2}$ Prasad later told us that in the Pacific more people are dying from climate change than from any other cause, including Covid. Levine said the US health system currently accounts for a quarter of all global emissions from health systems and pledged that the system would reach net-zero.

The US health system comprises many different organisations, many of them in the private sector, which must make it more difficult for the whole system to reach net zero. Indeed, all these countries will need a detailed plan, investment, and people if the grand promises are to become reality. 
Neira reappeared and handed over to Wendy Morton, a minister in the Foreign, Commonwealth, and Development Office. (I'd never heard of her, and when I reflect on all the junior ministers who have come and gone in the 50 years I've been paying attention to government, I realise that they are people with little power, most of whom leave no mark whatever.) Morton conducted a panel discussion with seven people, some of whom read their answers to scripted questions.

Brown was by far the best speaker, emphasising that if rich countries do not transfer at least $\$ 100$ billion a year to poorer countries vulnerable to climate change then the aim of keeping global increases to below $1.5 \mathrm{C}$ will not be achieved. He reminded the audience that that promise had been made in Copenhagen in 2009, but had never been fully met. He drew a parallel with the failure of rich countries to provide sufficient amounts of Covid vaccine to poorer countries.

The transfer of funds is best thought of not as aid or charity, but as reparation, compensation for abuse and damage. It's the rich countries that industrialised early that have caused the problem of climate change, and the rich countries have become rich in part by exploiting poorer countries: Britain is estimated to have "stolen" \$45 trillion from India and benefited greatly from the slave trade. ${ }^{3}$

\$10o billion might seem like a lot of money, but it's less than the annual cost of the NHS and trivial when you consider that global GDP is $\$ 80$ trillion.

After the panel discussion, Gillian Keegan, minister of state for care at the Department of Health and Social Care, described how NHS England had a plan to reach net zero and had reached its first-year target and announced that the National Institute for Health Research had a fund of £2o million for research into climate change and health. ${ }^{4}$

After the session we scrambled for another photograph with the satchel and healthy prescription board and managed to get one that included many of the assembled dignitaries. We then chatted with a minister of the Egyptian government, the hosts of COP27, and he promised a full day for health at the next COP.

In my final session at $\mathrm{COP} 26$ I was part of a panel that told the story of how we had worked together to try and raise the voice of health professionals in discussions about climate change. I told the story of the editorial published in over 220 health journals, and others described the healthy prescription letter, the WHO report, and the Ride for Their Lives. ${ }^{5}$

There was a feeling that we had made progress, but we still have a long way to go. The final document from $\mathrm{COP} 26$ contains the word "health" only once and doesn't mention health systems:

"Acknowledging that climate change is a common concern of humankind, Parties [that is, countries] should, when taking action to address climate change, respect, promote and consider their respective obligations on human rights, the right to health, the rights of indigenous peoples, local communities, migrants, children, persons with disabilities and people in vulnerable situations and the right to development, as well as gender equality, empowerment of women and intergenerational equity." A lot of ideas are collapsed into one Proustian sentence, which Greta Thunberg might well call "blah, blah, blah."

"In the beginning was the Word," as the Bible says, but words without actions are useless.

As I travelled on the train back to London I tried to make sense of what I had just experienced. Perhaps the way to think of COP is of a system, even a machine, that is trying to drive the world's people to do what they must do to keep the planet inhabitable. At the centre of a series of concentric circles are the people at the negotiating table trying to reach an agreement that all 197 countries can support. I didn't see any of those people. Outside of them is an army of government staff with rich countries having hundreds and poor countries a handful. These supporting staff are among the thousands of people in the Blue Zone, who include lobbyists, academics, campaigners, business people, media, and many others. This group tries to influence the negotiators, and outside the COP altogether are the hundreds of thousands of people marching in the street, who are also trying to influence the negotiators.

Considering that the conference itself has a substantial carbon footprint, is it all necessary? Is it the best we can do? That the world is in such a sorry state after 25 previous COPs suggests that they are not very effective, but where would we be if there were no COPs at all? As climate change is a global problem, countries (or parties) have to come together to negotiate, but I'm not convinced that the circles outside the negotiators and their staff are necessary. I can't see that I would be justified in flying to Egypt for $\mathrm{COP}_{27}$, and it's a long cycle from Clapham to Sharm El-Sheikh. It is, according to Google, 3038.2 miles and would take 936 hours to walk. I'll contribute online.

Have I, I wonder as the train approaches London, been a minuscule part of a 21st century equivalent of the Versailles Peace Conference, which promised much but gave rise to the Second World War?

Competing interests: Richard Smith is the chair of the UKHACC and is former editor in chief of The BMJ.

The Global Climate and Health Alliance. https://climateandhealthalliance.org/news/climateprescription-video-why-world-leaders-must-take-climate-action-to-protect-our-health/

2 Countries commit to develop climate-smart health care at COP26 UN climate conference https://www.who.int/news/item/09-11-2021-countries-commit-to-develop-climate-smart-healthcare-at-cop26-un-climate-conference

3 How Britain stole $\$ 45$ trillion from India https://www.aljazeera.com/opinions/2018/12/19/howbritain-stole-45-trillion-from-india

$4 \quad$ NIHR announces package of funding for research on climate and health at COP26 https://www.nihr.ac.uk/news/nihr-announces-package-of-funding-for-research-on-climate-and health-at-cop26/29256

Atwoli L, Baqui AH, Benfield T, etal. Call for emergency action to limit global temperature increases, restore biodiversity, and protect health. BM/2021;374:n1734. doi: 10.1136/bmj.n1734. pmid: 34483099 